\title{
The Causality and Elasticity of Defense
}

\author{
Okyeon Yi Hong* \\ (Korea National Defense University)
}

\section{$\langle$ Contents}

I. Introduction

II. Literature Review

III. III. Model Specification
IV. Descriptive Analysis, a.k.a. Eyeballing

V. Empirical findings and implication

VI. Conclusion

- Keywords: defense spending, economic growth, Asian NICs, causality, elasticity

\section{【 ABSTRACT 】}

To analyze the observed trend in the temporal fluctuations of defense spending, I select three Asian NICs for the period of 1968-1999 and employ the causality and elasticity models. The Hsiaso causality test is especially helpful in specifying the interrelationship between defense spending and economic growth. Based on findings from the causality test, the elasticity model is particularly resourceful in constructing how the level of spending on defense is conditioned distinctively among seemingly similar countries. This paper is an attempt to improve the research on the economics of defense in the following ways: 1) it targets three Asian NICs that share a certain common traits but not others such that some obvious factors are held constant, 2) it concentrates on a longitudinal change in the interconnection between defense and growth rather than its cross-sectional variation, and 3) it introduces the elasticity model to address systematically the interstate difference in the interrelationship between defense and growth, which is observed through the causality test.

* For extremely helpful discussions of an earlier version of this paper, I thank three anonymous reviewers. I thank Glenn Palmer who chaired my thesis committee and gave me the scintillating title of my thesis, Three Tigers and Defense a long time ago. I also gratefully acknowledge Michael McDonald whose comments improved the final draft of my thesis and Wing T. Woo who has encouraged and still encourage me to stay interested in Korean issues. 


\section{I . Introduction}

Military expenditure is by itself an emotional subject. On the one hand, money spent on defense provides security to a country. On the other hand, one's armament can sometimes lead to arms race, if not violent confrontation ultimately. The increase in the military expenditure of one country, in other words, can be interpreted as an aggressive action toward the preparation for a war by an adjacent country in a hostile relation. Furthermore, defense spendingaside from its security concernsbears economic significance, largely because it is also a segment of the national economy. The military sector, however, may or may not generate economic consequences in accordance with its positive or negative impact on the national economy. This paper addresses the latter economic effect of defense spending in South Korea, Singapore, and Taiwan for the period of 1968-1999. In this paper, I will specifically explore the interconnection between defense spending and national economy regarding the direction of causation and the elasticity of defense spending in these three Tigers.

Since Benoit's provocative argument that military expenditures are to influence growth, various scholars employed a wide range of models and drew an equally wide range of conclusions. ${ }^{1)}$ Adopted models are largely broken into supply side, demand side, or some combination of both. While a majority of demand-side models revealed a negative impact of defense spending on economic growth, a supply-side approach often yields a positive influence, especially in some less developed countries. ${ }^{2)}$ Nevertheless, it remains unclear whether the net effect of defense spending is positive or negative. More importantly, defense spending is shown to have no significant influence on economic growth in most recent supply-side studies.3) In this paper, I will clarify the direction of causality and elasticity of defense spending in an effort to identify the interrelationship between defense spending and economic growth.

To accomplish this objective, I will selectively review previous works on defense and economy, specify models of causality and elasticity in sequence, describe temporal trends in economic growth and defense spending in three Tigers, report empirical findings from the respective analysis, and draw conclusions. This paper presents, in no way, a thorough exposition of the defense-economy interrelationship. In this paper, however, I attempt to pick up what others left behind, especially with regard to the Asian NICs that appear to share many common traits. Therefore, this paper is an improvement over previous works,

1) Benoit 1973, 1978.

2) Sandler and Hartley 1995, Table 8.2 "Review of literature on growth and defense," pp. 216-219.

3) Biswas and Ram (1986), Huang and Mintz (1990), Alexander (1990), Huang and Mintz (1991), Adams et al. (1991), Mintz and Stevenson (1993). Ward et al. (1990) is an exception to this finding in which the military expenditure is shown to have a positive impact on economic growth in India during 1950-1987. Ward and Davis (1992) show that the military expenditure had a net negative impact on economic growth, but that externality effect is positive in U.S. during 1948-1990. 
precisely because it addresses how seemingly similar countries perceive its security needs. Many scholars employed the Granger-causality test to ascertain the presence and/or direction of causation between defense and growth. In addition to this question of causality, I will elucidate the elasticity of defense spending to illuminate how capable and willing a country is in intermingling economic and security goals.

\section{Literature Review}

Even though numerous studies suggest that there should be a certain relationship between defense expenditure and economic growth, scholars rarely agree on the nature, if not the presence, of a relationship between defense and economic performance. Benoits study opened the door to the study of defense and growth when he boldly concluded that a direction ran primarily from defense to growth. ${ }^{4}$ Most other researchers, however, remain skeptical that defense spending can exert a direct effect on economic growth, although they generally agree that military spending does generate side effects on the economy independent of the security aspects.5) That is, defense expenditures confer or impose on economic growth. The benefits of military expenditures include 1) a stimulative effect from defense expenditures, especially during periods of unemployment, 2) direct technological effects and spin-offs from the defense sector to the civilian sector, 3) social infrastructure and other public goods,6) 4) human capital enhancing activities,7) and 5) a secure environment both within and without. The military expenditures may also inhibit growth by 1) diverting resources away from public and private investment, 2) promoting capital inflows, especially if a country imports arms, 3) diverting $R \& D$ activities from the private sector, 4) diverting resources from the export sector, and 5) burdening the economy through inefficient bureaucracies and heavy tax.

As a full-blown model is supposed to incorporate both the supply-side influences and the demand-side factors, the complicated interrelationship between defense and growth is largely an empirical question. Scholars often subgroup countries in a sample such that differences between countries of different groups are internalized in the model. Frederiksen and Looney divide 37 LDCs on the basis of financial constraint and find that the resource-unconstrained LDCs indeed experience a direct positive impact after controlling for bilateral aid.8) Looney and Frederiksen produce a similar result when the external public debt is included in place of bilateral aid.9) Lim divides 54 LDCs based on geographic

4) Benoit 1978 .

5) Biswas and Ram 1986, Sandler and Hartley 1995.

6) Classic examples include dams, roads, airports, communication networks and so forth.

7) The military sector may provide nutrition, training, and education to a segment of the population, thus impacting the civilian sector, especially in less developed countries.

8) Frederiksen and Looney 1982. 
locality instead and still finds a direct positive relationship.10) Frederiksen and Looney replicate Lims analysis with 95 LDCs divided on the basis of financial resource constraint and find that financially unconstrained LDCs do exhibit a significant and positive relationship between defense and economic growth. ${ }^{11)}$ It remains debatable, however, how and why geographical proximity can function as a proxy of the level of resource constraint.

To elaborate how a military sector boosts other sectors and thus enhance economic growth, i.e. the supply-side influences, scholars need to prove that the military spending contributes to the productivity of the economy as a whole. After hypothesizing that military spending may generate spin-off through training, research \& development, military-industrial complex, construction of infrastructure, and fuller utilization of overall productive facilities, Deger and Sen conclude from their finding that spin-off to non-defense sector does little to boost economic growth. ${ }^{12)}$ More importantly, a military sector must be shown to generate positive effects over and above those generated by the alternative sector. That is, if the money spent on investment proves to be more productive, industrial equipment, not the military expenditure, contributes to economic growth much more effectively. ${ }^{13)}$ Thus spin-off from a defense sector to non-defense sectors is unlikely in many resource-constrained LDCs because newly created demands for unutilized or underutilized productive capacity cannot be absorbed in other sectors in which resource constraint is endemic, whereas money spent on defense does not aggravate burdens on the economy and even boosts the civilian output sector in financially unrestrained LDCs.14) Adams et al. further divide the economic sectors into export, government and non-export non-government, and find a positive spin-off, which, however, turns insignificant when government expenditure is decomposed into military and non-military components.15)

From the demand-side perspective, the resources allocated to defense are foregone opportunity costs to the alternative sector, be it savings/investment or non-military consumption. While the supply-side models are inherently associated with a positive impact of defense on growth, the demand-side models forebode a negative impact as the military expenditures crowd out savings, investment, export, etc. Deger and Smith refute Benoits conclusion and argue that military expenditure dampens economic growth by reducing savings.16) Deger and Sen also conclude that defense spending crowds out investment, which deters economic growth, as does Rothchild that military spending lowers export growth, which is detrimental to economic growth. 17) Mintz and Huang further

9) Looney and Frederiksen 1986.

10) Lim 1983.

11) Frederiksen and Looney 1983.

12) Deger and Sen 1983.

13) Deger 1986.

14) Biswas and Ram 1986, Biswas 1993.

15) Adams et al. 1991.

16) Deger and Smith 1983.

17) Deger and Sen 1983, 1990, Rothchild 1977. 
divide the economic sectors into private, non-military government and military, and confirm that military expenditure exerts a negative impact on economic growth via the reduced investment in the private sector. ${ }^{18)}$

The so-called peace dividend argument has caught the attention of scholars and policymakers alike in the post-Cold War period, as fewer guns mean more butterimmediate or delayed. Huang and Mintz incorporate productivity differentials along with externality effect of military and non-military spending, and when Mintz and Stevenson expand the sample to 103 countries, they all find that the impact of military component of government spending is shown to be significant only in a small segment of the sample.19) Heo includes the technological change factor in the model and finds that technological progress in the private sector exerts a significant effect on economic growth in 51 out of 80 countries, while military externality effects are significant only in 18 countries. ${ }^{20)}$ When Heo and DeRouen focus on the East Asian NICs known to juggle with 'security-prosperity dilemma' constantly, they find that military spending has a negative, and often significant, effect on economic growth. ${ }^{21)}$

Although Benoit never intended to draw attention to a causal relationship between defense and growth, his daring studies still manage to provoke debate. Joerding criticizes all the Benoit-like studies on the ground that domestic economy may partially explain the level of defense spending and finds that military spending is indeed fiscally constrained in testing for Granger-causality of 57 LDCs.22) Frederiksen and LaCivita object to lumping all the countries into one as Joerding does and compares the results between when the lag length is 4 as in Joerding's study and when it is 2.23) When the lag is set to 2, economic growth Granger-causes defense spending, but when the lag is set to 4 , they find no significant relationship between the two variables. As the arbitrary choice of the lag length determines the outcome of analyses, LaCivita and Frederiksen use the Hsiao model and find that 11 out of 22 countries show an interdependent relationship.24) Looney also uses the Hsiao model to compare India and Pakistan, and finds that India, unlike Pakistan, can absorb the positive externality from its larger defense industry sector. ${ }^{25)}$ Chowdhury modifies the Granger-causality tests by incorporating the FPE criterion and concludes that the relationship between defense and economic growth differs among 55 LDCs, depending

18) Mintz and Huang 1991.

19) Huang and Mintz 1992, Mintz and Stevenson 1995. The impact of military spending is significant only in 10 percent of the sample. Moreover, the signs of the effect are mixed, 8 positive and 2 negative.

20) Heo 1998.

21) Heo and DeRouen 1998. Interestingly, Park (1993) points out that the neoclassical assumptions precipitate the distorted perspectives on the political economy of defense spending in LDCs.

22) Joerding 1986.

23) Frederiksen and LaCivita 1987.

24) LaCivita and Frederiksen 1991.

25) Looney 1991. 
on the sample period of study, resource constraint, and the type of government.26)

In his survey of the literature, Chan comments that the mixed results of the previous studies indicate a point of diminishing returns in relying on aggregate cross-national studies and suggests that studies of individual countries should provide us with meaningful findings. ${ }^{27)}$ Following the causality model, I will specify the income elasticity model in accounting for a distinctive manner of response by three Tigers. In doing so, I purport to explain the interstate difference among three similarly situated countries in the defense-growth interrelationship by integrating the universal explanatory model and individual study of sample countries.

\section{Model Specification}

\section{Research Design 1: Causality}

The specification of the causal relationship between defense expenditure and economic growth is indeed a comerstone for research on the nature of such a relationship. To investigate the lag structure of defense and economy, including possible differences among countries, I will use the Hsiao model instead of the Granger model because the former allows the systematic choice of the optimal lag structure for each variable and for each country. This choice is an improvement over the ad hoc nature of the Granger-causality test on a couple of accounts. First, since the Granger model assumes all the variables take the equal lag structure, there involves a risk of underfitting the model leading to inefficiency. The Hsiao model is attractive because it allows a specification of the equations without imposing artificial restrictions. ${ }^{28)}$ Second, the FPE (final prediction error) criterion is an improvement over the conventional hypothesis testing procedure because of the choice of significance level. The conventional choice of $5 \%$ or $10 \%$ significance level is ad hoc in deciding the inclusion of a variable. In contrast, the FPE criterion helps us decide whether to include a variable in an equation on the basis of the minimum mean square error. 29$)$

The first step is to perform a series of autoregressive regressions on the dependent variable like the following:

26) Chowdhury 1991. Kusi draws a similar conclusion for 77 LDCs, using the Granger-causality tests (1994).

27) Chan 1985, p. 433.

28) Hsiao 1981, p. 87.

29) Hsiao 1979 , pp. 326-327. The Hsiao model has an optimal property "to balance the risk due to bias when a lower order is selected and the risk due to increase in variance when a higher order is selected." 


$$
\mathrm{GDP}_{\mathrm{t}}=\alpha+\sum_{\mathrm{i}=1}^{\mathrm{m}} \mathrm{BGDP}_{\mathrm{t}-\mathrm{i}}+\varepsilon_{\mathrm{t}}
$$

For each regression, $\mathrm{FPE}(\mathrm{m})$ is computed in the following manner:

$$
\operatorname{FPE}(\mathrm{m})=\left[\begin{array}{c}
\mathrm{T}+\mathrm{T}+1) /(\mathrm{T}-\mathrm{m}-1)]^{*} \mathrm{ESS}(\mathrm{m}) \\
\mathrm{T}
\end{array}\right.
$$

In the above computation, $\mathrm{T}$ is the sample size, ESS(m) is the sum of squared errors, and $m$ is the lag length. The optimal lag length is one that produces the lowest FPE. The next step is to add lags on the other variable sequentially as in the first step:

$$
\operatorname{GDP}_{\mathrm{t}}=\alpha+\sum \underset{\mathrm{i}=1}{\mathrm{~m}} \operatorname{GDP}_{\mathrm{t}-\mathrm{i}}+\sum \underset{j=1}{\gamma_{j=1} \mathrm{DEF}_{\mathrm{t}-\mathrm{j}}+\varepsilon_{\mathrm{t}}}
$$

For each regression, $\operatorname{FPE}(\mathrm{m}, \mathrm{n})$ is computed in the following manner:

$$
\frac{F P E(m)=[(T+m+n+1) /(T-m-n-1)]^{\star} E S S(m, n)}{T}
$$

The optimal lag length is one that produces the lowest FPE.

To test for the causality, compare $\mathrm{FPE}(\mathrm{m})$ with $\mathrm{FPE}(\mathrm{m}, \mathrm{n})$. If $\mathrm{FPE}(\mathrm{m})<\mathrm{FPE}(\mathrm{m}, \mathrm{n})$, the prediction error for growth is not reduced when defense is added to the equation. Thus defense does not Granger-cause growth. Contrarily if $\operatorname{FPE}(m)>\operatorname{FPE}(m, n)$, the prediction error for growth is reduced with defense added as an independent variable. Thus defense Granger-causes growth. The causality test is complete if a similar regression estimation is carried with defense spending as a dependent variable as in the following:

$$
\begin{aligned}
& \mathrm{DEFt}=\chi+\sum \stackrel{\mathrm{r}}{\delta_{\mathrm{i}} \mathrm{DEF}_{\mathrm{t}-\mathrm{i}}}+\sum \stackrel{\mathrm{s}}{\eta_{\mathrm{j}} \mathrm{GDP}_{\mathrm{t}-\mathrm{j}}+\psi_{\mathrm{t}}} \\
& \mathrm{i}=1 \quad \mathrm{j}=1
\end{aligned}
$$

Then, four cases are possible: ${ }^{30}$ )

1. Defense causes growth when

30) In a multiple autoregressive model, the least squares estimates of each equation is assumed consistent and asymptotically normally distributed for contemporaneously correlated white noise residuals (Hsiao 1981, p.91). However, when the coefficient of the error term is statistically significant, there is an indication of contemporaneous correlation. If the residuals of the model are serially correlated, the OLS estimates are inefficient, though unbiased, and will distort the causal relationships. To check for serial correlation, I will use a maximum likelihood correlation for the first-order autocorrelation of the residuals. 
$\mathrm{FPE}(\mathrm{m})$ for growth $>\mathrm{FPE}(\mathrm{m}, \mathrm{n})$ for growth FPE(r) for defense $<$ FPE(r,s) for defense

2. Growth causes defense when $\mathrm{FPE}(\mathrm{m})$ for growth $<\mathrm{FPE}(\mathrm{m}, \mathrm{n})$ for growth FPE(r) for defense > FPE $(r, s)$ for defense

3. A feedback between defense and growth $\mathrm{FPE}(\mathrm{m})$ for growth $>\operatorname{FPE}(\mathrm{m}, \mathrm{n})$ for growth FPE(r) for defense $>$ FPE( $r, s)$ for defense

4. No relationship between defense and growth ${ }^{31}$ ) $\mathrm{FPE}(\mathrm{m})$ for growth $<$ FPE $(\mathrm{m}, \mathrm{n})$ for growth $\mathrm{FPE}(\mathrm{r})$ for defense $<\operatorname{FPE}(\mathrm{r}, \mathrm{s})$ for defense

\section{Research Design 2: Elasticity}

Benoit argues that the only possible role economic constraints play is to set a ceiling on the amount of money spent on defense. ${ }^{32}$ ) Yet the extent of economic constraint often varies from country to country depending on the income elasticity of defense demands. That is, the degree of constraint depends on the degree of weight placed on the security requirement in relation to economic needs. To explain the interstate difference, I will examine how economic capacity plays a decisive role in conditioning the level of military expenditure. In economics, income elasticity of demand measures the percentage change in purchases of good $\mathrm{X}$ due to a percentage change in income. ${ }^{33)}$ The larger the elasticity coefficient is, the more responsive purchasers are to changes in income. In the relationship between GDP and defense spending, the income elasticity of demand for defense indicates how essential defense expenditure is perceived to be by a country. By measuring the degree of priority a country places on defense, elasticity of defense spending, therefore, illuminates the distinctive perception of security demands by a particular country. ${ }^{34)}$

The more elastic defense is, the less a country regards its security needs as essential. If defense is very elastic, i.e., if income elasticity of defense demand is greater than 1 , a country does not put much weight on the significance of defense, especially when the economy is sluggish. Accordingly, defense is treated like any other expenditure, subjected to and constrained by resource availability, since a country does not regard the defense requirement as essential so that it unreservedly compromises economic and security goals. However, if defense is inelastic, i.e., if income elasticity is less than 1 , a country perceives

31) If two events occur simultaneously, it is difficult to tell which causes which in a time series setup. Thus even though the residuals are contemporaneously correlated, the causal relationship is expressed as inertia within the system. Accordingly, it is necessary to check if no relationship means exogeneity or instantaneous causality.

32) Benoit 1973, 1978.

33) Steven Call and William Holahan, Microeconomics (Belmont: Wadsworth Publishing Co., 1983).

34) Palmer 1991. 
its national security to be vital for its survival, even when a sign of recession is imminent. Because a country is unwilling to compromise its security needs with other economic needs such that defense is relatively free from economic constraint, the level of resource availability does not play a significant role in determining the level of military expenditure. In other words, a country places a high priority on defense needs such that defense is considered a necessity.

The following equation determines the income elasticity of defense spending:

$$
\begin{gathered}
\operatorname{Ln}(\text { defense spending) }=\alpha+\beta * \operatorname{Ln}(\text { GDP per capita) } \\
\therefore \text { defense spending }=\mathrm{e}^{\alpha} \text { GDP per capita }{ }^{\beta}
\end{gathered}
$$

The first part of the right-hand side of Equation $1, \mathrm{e}^{\alpha}$, is the slope of defense spending curve, while $\beta$ indicates the change in the slope of defense spending curve, i.e. elasticity of defense spending. ${ }^{35)}$ The level of economic performance is an important determinant of the level of defense spending aside from security needs, if a country is willing to swap its security needs for economic concerns, i.e., if $\beta>1$. Meanwhile, defense spending is relatively less constrained by resource availability, if a country does not give up its security goals willingly on the basis of economic constraint, i.e. if $\beta<1$.

\section{Data sources, price conversion, and variables}

All the military expenditure data are from the SIPRI Yearbook. The military expenditure data are known to be inaccurate, incomplete, or both. Aside from genuine problems of definition and measurement, intentional misinformation undermines its reliability. As mentioned earlier, military expenditure is, by nature, related to national security. Because ones own national security may mean the others insecurity, countries tend to provide misinformation about the actual amount spent on the military sector for strategic and psychological reasons.36) Despite these problems, the trends observed in defense spending are largely consistent. ${ }^{37)}$ Annual data on GDP and other macroeconomic variables are from the International Financial Statistics Yearbook, although the economic data for Taiwan are from the Statistical Yearbook of the Republic of China.

All the raw data are from the most recent version and in current local currency, thus price conversion is necessary for interstate comparison. Current local currency expenditures are first converted to US dollars via average annual market or official exchange rates. Since these rates do not reflect the accurate relative purchasing power of the currency and comparison of the data at current price bears little meaning, GDP deflators are used. Consumer Price Indexes, or CPI, are commonly used to reflect changes in the cost of acquiring a fixed amount of goods and services by the average consumer. However, CPIs are basically for private final consumption of households, whereas overall GDP deflators

35) $\mathrm{e} \approx 2.71828$.

36) Deger 1990.

37) For specific details, refer to Yi Hong (2003b). 
represent average rates of inflation within an economy as a whole. ${ }^{38)}$ Depending on the choice of price deflators, the adjusted expenditures come out differently. Although the absolute numbers differ, the trend in the fluctuations of expenditure is generally consistent so that the interstate comparison stands valid as long as I use the identical price deflator for all three Tigers and for all the variables. ${ }^{39)}$

GDP per capita is used as a measure of economic growth to reflect the different size of population, while the level of military expenditure is used since defense is a classical public good, i.e., the marginal cost of defense is assumed to be zero. Although the defense burden, i.e., military expenditure as percentage of GNP, GDP, or government expenditure, is more commonly used, it solves neither a problem of interstate comparability nor a built-in bias due to its relation to the progress in the national economy. ${ }^{40)}$

\section{Descriptive Analysis, a.k.a. Eyeballing}

Figure 1 depicts GDP per capita and defense expenditure in South Korea. Except for the post-1997 financial crisis, South Korea experienced a steady economic growth. Contrarily, defense expenditure grew rather abruptly at times and showed very little temporal change at other times. Throughout the twenty-year period, the growth of military expenditure in South Korea displayed a periodic volatility, which was not always coincidental with the observed economic growth. This seemingly hard-to-predict relationship between defense expenditure and economic growth found in South Korea contrasts with a qualitatively distinctive one observed in Singapore.

$\langle$ Figure 1〉 Defense and growth in South Korea

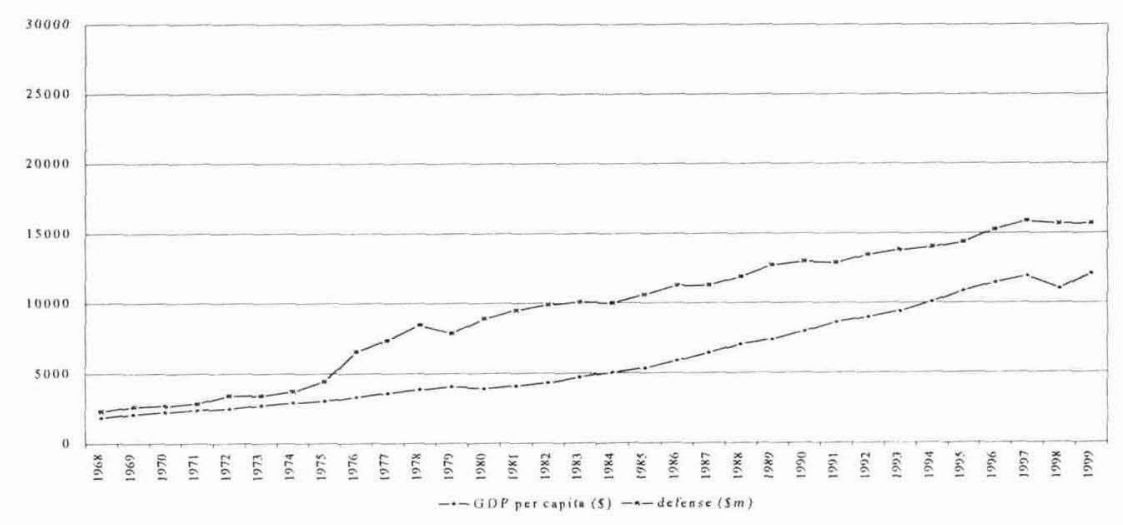

38) Nevertheless, overall GDP deflators do not completely reflect inflation rates in individual sectors.

39) For more details, refer to Hong (1992), Table 2, p. 44. For the purpose of comparison, I selectively compared Singapore's GDP by using GDP deflator and CPI. A noticeable discrepancy was indeed found but largely limited to the earlier period, thus I concluded that both indicators of price conversion were acceptable as long as the identical one was in consistent use.

40) For more details, refer to Yi Hong (2003), Table 1, p. 88. 
Figure 2 illustrates very different patterns of economic growth and military spending in Singapore for the identical period. Although the Singaporean economy expanded much faster than its share of military spending did, one's growth can arguably boost the other's growth, or vice versa. The precise nature of such an interrelationship is, however, far from clear here. This apparent indeterminateness poses an interesting puzzle to explain the exact relationship between growth and defense observed in Singapore. Figure 3 shows that economy and military spending seemed to grow in tandem in Taiwan, except for the recent decade when spending on defense contracted. Yet unlike in Singapore, changes in military spending occurred periodically as in South Korea although defense spending in Taiwan rarely exhibited an abrupt kinks as observed in South Korea, except for the recent decade.

$\langle$ Figure 2〉 Defense and growth in Singapore

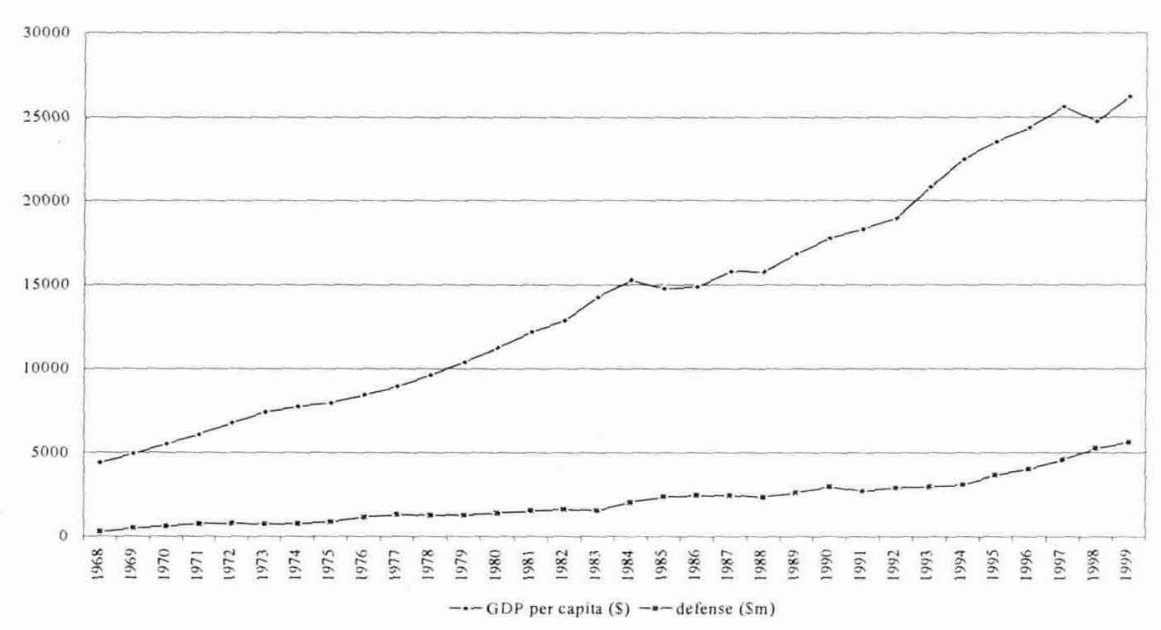

$\langle$ Figure 3〉 Defense and growth in Taiwan

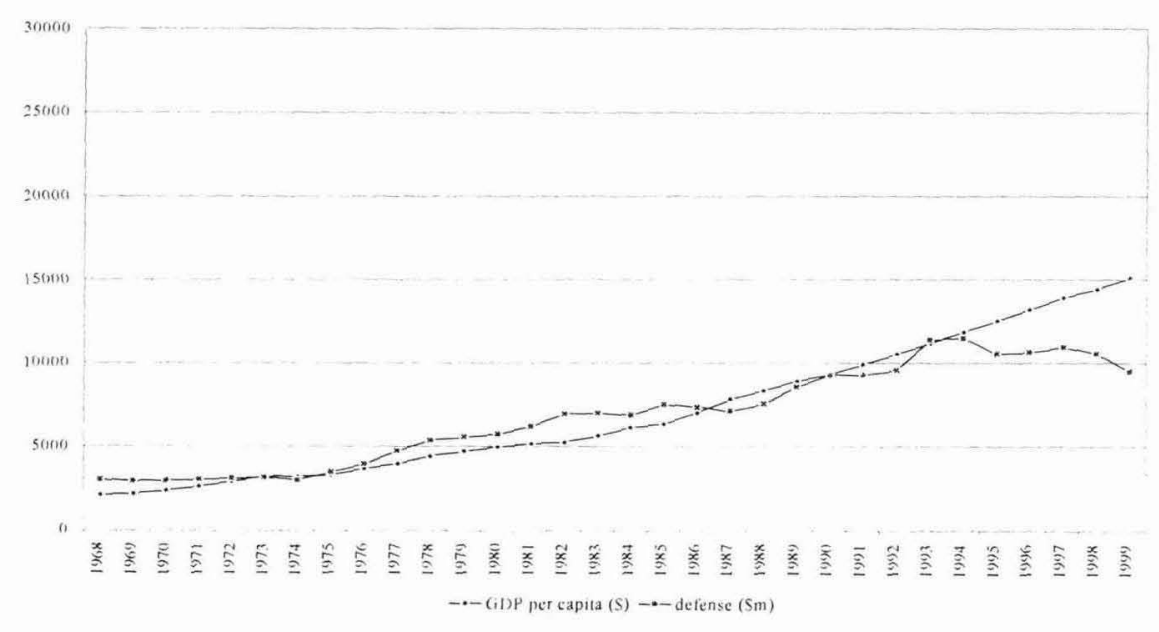


As can be seen above, eyeballing general patterns in changes is woefully insufficient in explaining how one growth is related to the other and why it is so in each Tiger. In next section, I will strive to tackle this problem by exploring the direction of causation between economic growth and military spending, followed by the elasticity of defense expenditure.

\section{Empirical findings and implication}

\section{Findings from the Causality Test}

As mentioned earlier, the Hsiao model allows the different lag structure for each variable. In so doing, the optimal lag structure with the minimum mean squared error is chosen and used to test the causality without a priori restrictions on the lag length. The empirical results from the Hsiao causality test using the OLS estimation are reported in Table 1. Then, to check for the existence of serial correlation of the disturbance terms, a maximum likelihood correlation for the first-order autocorrelation of the residuals is used. The results from the $\mathrm{AR}(1)$ estimation are reported in Table 2. Upon comparing both results, I do not find any significant changes in the causal direction. Thus I presume that serial correlation of $\mu_{\mathrm{t}}$ and $\nu_{\mathrm{t}}$ is not serious in this model.

From Table 1 and 2, defense spending and economic growth are interdependent in Singapore, whereas no relationship exists between defense and growth in South Korea. Defense spending is shown to boost economic growth in Taiwan, though. As mentioned earlier, no relationship shown in the causality test can be interpreted either as non-causality or as instantaneous causality due to contemporaneous correlation of the residuals. The regression of the residuals from two equations indicate no such a correlation, thus I conclude that no significant relationship exists between defense and growth in South Kore a. ${ }^{41)}$ To explain this interstate difference, the interdependent relationship is decomposed into two-way causality.

41) The regression equations are the following:

$$
\begin{aligned}
& \mathrm{RGDP}=\alpha+\beta * \mathrm{RDEF}+\varepsilon, \quad \mathrm{RDEF}=\chi+\delta * \mathrm{RGDP}+\gamma \\
& 0.05(0.4) \quad 0.11(0.4)
\end{aligned}
$$

where the number the parentheses is t-statistics. RGDP and RDEF are the residuals of two equations with GDP and DEF as a dependent variable respectively. None of the coefficients are statistically significant. 
〈Table 1 > OLS estimation of the Hsiao causality model

\begin{tabular}{|c|c|c|c|c|c|c|}
\hline \multicolumn{7}{|c|}{ Dependent variable: defense expenditure } \\
\hline $\begin{array}{l}\text { South Korea } \\
\text { No relation }\end{array}$ & $\begin{array}{c}\text { FPE }(r, s) \\
\text { DEF(-1) } \\
0.97^{\star} \\
(16.43)\end{array}$ & $\begin{array}{l}(1,1), \text { DW } \\
\text { GDP(-1) } \\
0.02 \\
(0.24)\end{array}$ & $=1.86$ & & & \\
\hline $\begin{array}{l}\text { Singapore } \\
\text { GDP DEF }\end{array}$ & $\begin{array}{c}\operatorname{FPE}(r, s) \\
\operatorname{DEF}(-1) \\
0.98^{\star} \\
(5.26)\end{array}$ & $\begin{array}{c}(1,4), \mathrm{DW} \\
\text { GDP(-1) } \\
0.07 \\
(0.94)\end{array}$ & $\begin{array}{c}=1.82 \\
\text { GDP(-2) } \\
-0.01 \\
(-0.1)\end{array}$ & $\begin{array}{c}\text { GDP(-3) } \\
0.12 \\
(0.94)\end{array}$ & $\begin{array}{r}\text { GDP }(-4) \\
-0.16^{*} \\
(-1.81)\end{array}$ & \\
\hline $\begin{array}{l}\text { Taiwan } \\
\text { No relation }\end{array}$ & $\begin{array}{c}\operatorname{FPE}(r, s) \\
\operatorname{DEF}(-1) \\
1.5^{\star} \\
(7.6)\end{array}$ & $\begin{array}{l}(4,2), \mathrm{DW} \\
\mathrm{DEF}(-2) \\
-1.15^{\star} \\
(-3.75)\end{array}$ & $\begin{array}{l}=2.22 \\
\mathrm{DEF}(-3) \\
1.11^{*} \\
(3.72)\end{array}$ & $\begin{array}{c}\operatorname{DEF}(-4) \\
-0.54^{\star} \\
(-2.31)\end{array}$ & $\begin{array}{c}\mathrm{GDP}(-1) \\
0.9 \\
(1.44)\end{array}$ & $\begin{array}{c}\text { GDP(-2) } \\
-0.92 \\
(-1.46)\end{array}$ \\
\hline
\end{tabular}

Dependent variable: GDP per capita

\begin{tabular}{|c|c|c|c|c|c|}
\hline $\begin{array}{l}\text { South Korea } \\
\text { No relation }\end{array}$ & $\begin{array}{c}\text { FPE }(m, n) \\
\text { GDP(-1) } \\
0.98^{*} \\
(18.46)\end{array}$ & $\begin{array}{c}=(1,1), D \\
\text { DEF(-1) } \\
0.04 \\
(1.17)\end{array}$ & $V=2.19$ & & \\
\hline $\begin{array}{l}\text { Singapore } \\
\text { DEF GDP }\end{array}$ & $\begin{array}{c}\text { FPE(m,n) } \\
\text { GDP(-1) } \\
0.91^{*} \\
(9.88)\end{array}$ & $\begin{array}{l}=(1,4), \mathrm{D} \\
\mathrm{DEF}(-1) \\
-0.82 \\
(-1.4)\end{array}$ & $\begin{array}{c}\mathrm{V}=2.11 \\
\mathrm{DEF}(-2) \\
0.86 \\
(0.97)\end{array}$ & $\begin{array}{c}\text { DEF(-3) } \\
-0.48 \\
(-0.54)\end{array}$ & $\begin{array}{c}\operatorname{DEF}(-4) \\
1.26^{*} \\
(1.8)\end{array}$ \\
\hline $\begin{array}{l}\text { Taiwan } \\
\text { DEF GDP }\end{array}$ & $\begin{array}{l}\text { FPE }(m, n) \\
\text { GDP(-1) } \\
1.17^{*} \\
(6.26)\end{array}$ & $\begin{aligned} &=(2,1), D \\
& \text { GDP }(-2) \\
&-0.17 \\
&(0.9)\end{aligned}$ & $\begin{array}{c}V=1.98 \\
\mathrm{DEF}(-1) \\
0.05 \\
(1.55)\end{array}$ & & \\
\hline
\end{tabular}

$\mathrm{GDP}_{\mathrm{t}}=\mathrm{f}\left(\Sigma \mathrm{GDP}_{t-n,}, \Sigma \mathrm{DEF}_{t-\mathrm{m}}\right), \mathrm{DEF}_{\mathrm{t}}=\mathrm{f}\left(\mathrm{DEF}_{\mathrm{t} \cdot \mathrm{r}}, \mathrm{GDP}_{\mathrm{t} \cdot \mathrm{s}}\right) \quad$ *: significant at $10 \%$ level

First, economic growth has an influence on the level of defense expenditure. That is, the availability of resources controls the decision to spend how much on defense. Although this result refutes Benoit's argument that the main determinant of defense expenditure is the political and/or military need, many researchers agree that the economic constraintsapart from security requirementpotentially have influences on the level of military spending. ${ }^{42)}$ My findings from the Hsiao causality tests indicate that the level of economic performance does indeed influence the level of military spending. The extent of such an effect depends on how elastic defense demand is in relation to the resources availability, or more precisely, the perception of such needs.

42) Benoit 1978, Maizels and Nissanke 1986, Looney and Frederiksen 1988. 
$\langle$ Table 2$\rangle \mathrm{AR}(1)$ estimates of the Hsiao causality model

\begin{tabular}{|c|c|c|c|c|c|c|}
\hline \multicolumn{7}{|c|}{ Dependent variable: GDP per capita } \\
\hline $\begin{array}{l}\text { South Korea } \\
\text { No relation }\end{array}$ & $\begin{array}{l}\text { FPE }(m, n) \\
\text { GDP(-1) } \\
0.98^{\star} \\
(21.85) \\
\end{array}$ & $\begin{array}{c}=(1,1), \mathrm{D} \\
\mathrm{DEF}(-1) \\
0.05 \\
(1.26)\end{array}$ & $N=1.97, \rho=$ & 0.188 & & \\
\hline $\begin{array}{l}\text { Singapore } \\
\text { DEF GDP }\end{array}$ & $\begin{array}{l}\text { FPE }(m, n) \\
\text { GDP(-1) } \\
0.94^{*} \\
(10.64) \\
\end{array}$ & $\begin{array}{c}=(1,4), \mathrm{D} \\
\mathrm{DEF}(-1) \\
-0.97 \\
(-1.62) \\
\end{array}$ & $\begin{array}{c}N=2.09, \rho= \\
D E F(-2) \\
0.92 \\
(0.99) \\
\end{array}$ & $\begin{array}{c}0.101 \\
\text { DEF(-3) } \\
-0.57 \\
(-0.61) \\
\end{array}$ & $\begin{array}{c}\operatorname{DEF}(-4) \\
1.3^{\star} \\
(1.82) \\
\end{array}$ & \\
\hline $\begin{array}{l}\text { Taiwan } \\
\text { DEF GDP }\end{array}$ & \multicolumn{6}{|c|}{$\begin{array}{lcc}\text { FPE }(m, n)=(2,1), D W=1.98, \rho=0.01 \\
\text { GDP(-1) } & \text { GDP(-2) } & \text { DEF(-1) } \\
1.16^{*} & -0.16 & 0.05 \\
(6.0) & (-0.83) & (1.53) \\
\end{array}$} \\
\hline \multicolumn{7}{|c|}{ Dependent variable: defense expenditure } \\
\hline $\begin{array}{l}\text { South Korea } \\
\text { No relation }\end{array}$ & $\begin{array}{c}\mathrm{FPE}(\mathrm{r}, \mathrm{s}) \\
\mathrm{DEF}(-1) \\
0.96^{*} \\
(14.76)\end{array}$ & $\begin{array}{l}(1,1), \mathrm{DW} \\
\text { GDP(-1) } \\
0.02 \\
(0.35)\end{array}$ & $=1.96, \rho=0$ & & & \\
\hline $\begin{array}{l}\text { Singapore } \\
\text { GDP DEF }\end{array}$ & $\begin{array}{c}\operatorname{FPE}(\tau, s) \\
D E F(-1) \\
0.87^{\star} \\
(4.37) \\
\end{array}$ & $\begin{array}{l}(1,4), \mathrm{DW} \\
\text { GDP(-1) } \\
0.08 \\
(0.98)\end{array}$ & $\begin{array}{c}=2.09, \rho=0 \\
\text { GDP }(-2) \\
-0.03 \\
(-0.21)\end{array}$ & $\begin{array}{l}08 \\
\text { GDP(-3) } \\
0.13 \\
(1.0) \\
\end{array}$ & $\begin{array}{c}\text { GDP }(-4) \\
-0.19^{*} \\
(-1.9)\end{array}$ & \\
\hline $\begin{array}{l}\text { Taiwan } \\
\text { No relation }\end{array}$ & $\begin{array}{c}\mathrm{FPE}(\mathrm{r}, \mathrm{s}) \\
\mathrm{DEF}(-1) \\
1.6^{*} \\
(8.24)\end{array}$ & $\begin{array}{l}(4,2), \text { DW } \\
\text { DEF(-2) } \\
-1.32^{\star} \\
(-4.2)\end{array}$ & $\begin{array}{c}=2.19, p=-c \\
\operatorname{DEF}(-3) \\
1.23^{*} \\
(4.0)\end{array}$ & $\begin{array}{l}142 \\
\text { DEF(-4) } \\
-0.63^{*} \\
(-2.73)\end{array}$ & $\begin{array}{c}\text { GDP(-1) } \\
0.93 \\
(1.49)\end{array}$ & $\begin{array}{l}\text { GDP(-2) } \\
-0.93 \\
(-1.47)\end{array}$ \\
\hline
\end{tabular}

The serial correlation is checked by using a ML method. *: significant at $10 \%$ level

Second, defense expenditure contributes to the economy in several ways. The most widely known effect is modernization, especially in LDCs. Modernization effect, however, may be difficultif not impossibleto measure because things like change in the attitudes requires an extraordinary operationalization. In the meantime, presuming that the military sector is at least as effective as the altemative sector, the provision of R\&D and advanced skills in the military sector diffuses technical progress to other sectors, which, in turn, reduce the average cost of production. ${ }^{43)}$ Furthermore, if there is a close linkage between the industrial and the military sector, the spin-offs from the military to the non-military sector can be absorbed to its optimum. ${ }^{44)}$

43) Deger and Sen 1983.

44) Because the spending in the military sector brings into the full utilization of a country's productive capacity, the spin-offs to certain industries may be beneficial to the overall economic growth. In this paper, I will not examine the extent of positive spin-offs from the military to the non-military sector. For more details, refer to Yi Hong (2003a). Along with the modernization and spin-off effect comes the notion that the opportunity cost of military spending is possibly foregone 


\section{Findings from the Elasticity Test}

Elasticity superbly measures how much a country is committed to its security goals. Table 3 lists the slope of the defense spending curve and the change in its slope. Confronted with a very powerful and hostile People's Republic of China (PRC), Taiwan has been involuntarily isolated in the international arena. ${ }^{45)}$ It severed diplomatic relations with Japan and terminated the Mutual Defense Treaty with the United States in 1979.46) Today few governments recognize Taiwan as a sovereign state, which is keenly aware that their prosperity depends on convincing prospective foreign investors and traders of its ability to defend itself.47) Therefore, its inelastic response to changes in economic capacity is no surprise: food comes after life. During the early years, Taiwan indeed increased its military spending in an accelerating manner, as shown in the slope $\left(=\mathrm{e}^{\alpha}\right)$ of 7.95 in Table 3 , indicating its desperate defense effort. Yet recently, Taiwan substantially modified its foreign policy. Taiwan is now more lenient to PRC and countries recognizing PRC.48) Elasticity $(\beta)$ less than 1 indicates that the change in the slope is decreasing, thus yielding a convex military expenditure curve in Figure 4 . Taiwans recent policy change arguably contributed to this observed slow-down effect. ${ }^{49)}$ Compared with the other two Tigers, however, the degree of response is smaller, indicating that Taiwan is much less likely to compromise security goals with economic needs.50)

〈Table 3〉 Income elasticity of defense spending

\begin{tabular}{c|c|c|c}
\hline & $\alpha$ & Slope (=e $\alpha)$ & Elasticity $(\beta)$ \\
\hline South Korea (1968-1999) & 0.5 & 1.65 & 1.0 \\
\hline Singapore (1968-1999) & -5.79 & 0.003 & 1.4 \\
\hline Taiwan (1968-1999) & 2.07 & 7.95 & 0.77 \\
\hline
\end{tabular}

South Korea is also faced with a formidable and unbending, if not unpredictable, North

consumption, not foregone investment. If so, it is a challenging task to compare the actual world with military spending with the hypothetical world with no such expenditure. To answer how the money saved from reduced or abolished defense expenditure is spent, Chan suggests a dynamic simulation model, which is beyond the range of this paper (Chan 1985, p. 432).

45) Taiwan lost its seat to PRC at the United Nations in 1971.

46) Taiwans severance of diplomatic ties with Japan followed the Japanese formal recognition of PRC. The diplomatic disconnection between U.S. and Taiwan, however, was largely limited to formal relations.

47) Deger 1986.

48) On the basis of 'pragmatic diplomacy,' Taiwan is more flexible in its international contacts (Shambaugh 1996).

49) Ward et al. 1993.

50) Davis and Chan 1993. 
Korea. However unlike Taiwan, South Korea still remains under the umbrella of the alliance with the United States. ${ }^{51)}$ Moreover, the military forces of the United States are stationed across South Korea and regularly participate in the joint military exercises with the South Korean armed forces. Therefore, South Korea feels less like a mouse in a corner, as seen in the slope $\left(=\mathrm{e}^{\alpha}\right)$ of 1.65 in Table 3 . Yet $\beta$ is almost equal to unity, i.e., the change in slope is arithmetically increasing, indicating that the military expenditure is proportionally responsive to the level of economic performance. Thus the level of economic welfare arguably affects the decision to set the appropriate level of defense spending to a certain degree.52) The challenging task, then, is to specify under what conditions defense spending is perceived as just another expenditure constrained by financial resource availability.

〈Figure 4> Income elasticity of defense spending

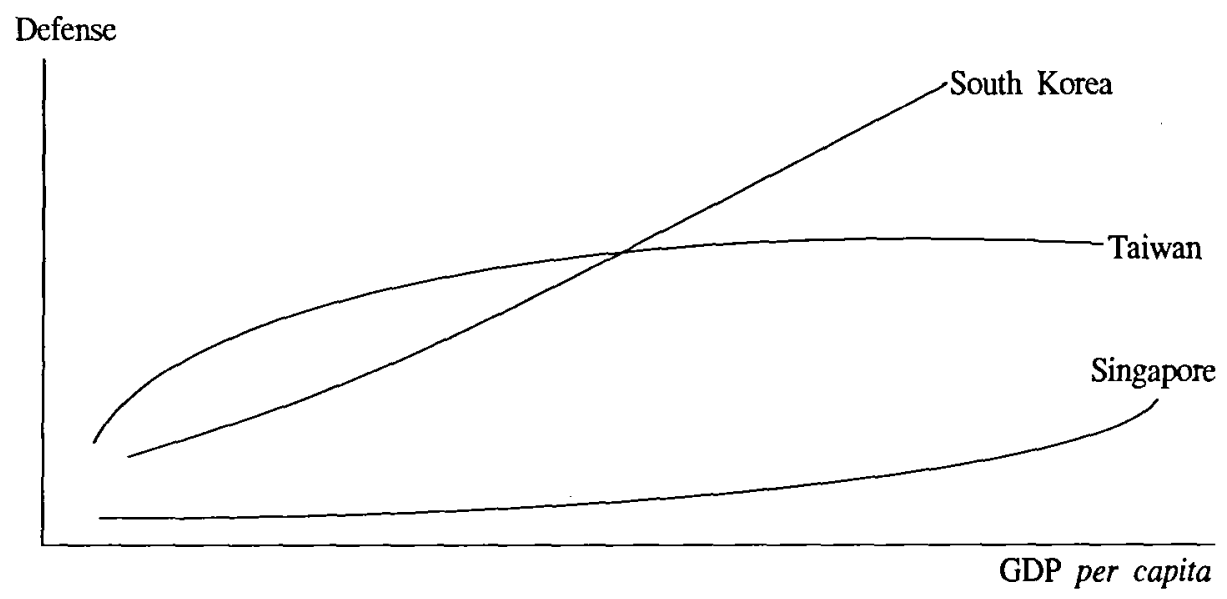

When national security is a political issue as much as it is a military issue, a high level of defense spending is often justified for political reasons. For example, the regime type is found to be a significant determinant of defense expenditure.53) Political leaders in some developmental states may feel it fortuitous to maintain defense forces in the name of security. Yet such political motives are subjected to financial constraint, not because they are particularly conscientious of fiscal conservatism but because they are keenly aware that a decent economic performance needs to be delivered to appease the public.54) Accordingly, political motives sometimes drive political leaders toward justifying the high level of defense spending despite the economic slow-down and other times toward

51) Moon and Hyun 1992. Despite recent strains in the relationship between Korea and US, both countries remain mutually committed to their alliance.

52) Heo 1990; Park 1993.

53) Maizels and Nissanke 1986; Hahm 1999.

54) Ball 1994. 
curtailing military expenditure because of the decline in economic growth. However, the extent to which the economy constrains the defense needs is much less in South Korea than in Singapore for an obvious reason: the 'North Korea problem,' or more precisely, the perception of its threat to national security.

In contrast to Taiwan and South Korea, Singapore does not have neighbors posing a prominent threat to national security. Yet its average annual growth rate of military expenditure persistently exceeds that of GDP. Singapore has been active in regional affairs such as the ASEAN and the Five-Power Arrangements, thus its level of military expenditure concurrently stays high.55) However, the primary determinant of the level of military spending is not grounded on military goals. Singapore keeps spending a consistently large sum of money on defense primarily because its economy is consistently performing well.56) The defense budget is, in fact, pegged to 6 percent of GDP.57) Since defense spending is just like any other consumption spending, a larger pie means a larger share to all the sectors in the economy. If the economy shows a sign of shrinking, Singapore is more than ready to sacrifice defense luxury in accordance with the declining rate of economic growth. In Figure 1, $\beta$ is highest of all three Tigers, i.e. defense needs are most elastic.

Moreover, unlike Taiwan, Singapores elasticity curve is concave, more so than Koreas. The slope $\left(=\mathrm{e}^{\alpha}\right)$ of 0.003 indicates the extent to which Singapore is far more lax about security concerns than South Korea is, but elasticity $(\beta=1.4)$ much larger than unity means that the change in slope is fast increasing as seen Figure 1. Singapores perception of security needs is indeed highly responsive to the level of economic performance. A larger largesse from the consistently high economic growth also makes it possible to pursue high-technology defense acquisition programs. ${ }^{58)}$ Even if the percentage change in defense burden is constant in Singapore, the absolute amount of military spending increases in tandem with the GDP growth rate. Such concomitance means that once economy sours defense suffers along with all the other sectors. Unlike South Korea and Taiwan, Singapore is immune from 'fears of the Dragons' despite Lee Kuan Yew's remark in early 1990.59)

\section{Conclusion}

Although every effort is made to be consistent in the data definition and collection,

55) $\mathrm{Li} 1997$.

56) Heo and DeRouen 1998.

57) The actual defense burden varied from 4.8 in 1992 to 4.0 in 1994 to 5.4 in 1998 (SIPRI Yearbook 2002).

58) Willett 1997.

59) " $\cdots$ the medium-size political powers-are bound to compete for power. This is simply human nature." (cited in Jonathan Sikes, Asia puts its wealth in military, Washington Times Feb. 12, 1990) 
such painstaking efforts fail to determine whether such accumulated data may imply either that one is committed to spending, or that one actually disbursed funds.60) Given the difficulty in decomposing the military spending and the vague distinction between the authorization and the actual spending, researchers find it challenging to analyze the trend observed in the temporal fluctuations of expenditure. Despite these and other handicaps, this paper confirms that the causality test is indeed a steppingstone to further the future study. The Hsiao model, in particular, is powerful yet parsimonious in specifying the appropriate system of explanation. The empirical results from the causality test show that there exists a feedback between defense and growth in Singapore, no relation exists between defense and growth in South Korea, and defense contributes to growth in Taiwan. The nature of an interrelationship, however, depends on circumstantial factors.

The elasticity model is attractive in that it spells out the conditions under a particular country will behave in a certain way. Thus, the extent to which the level of the economic performance determines the level of military spending is different from country to country, depending on its circumstantial differences and, more importantly, its perception of 'security-prosperity dilemma.' Unlike a descriptive analysis of case studies, the elasticity model captures such a differential extent of effect in a systematic way. A country that prioritizes security goals tends to be inelastic to changes in resource availability, whereas a country that does not feel threatened by its neighbors tends to be elastic to its economic constraint.

Taiwan, void of an official military ally, must encounter the People's Republic of China and convince its investors of its security, thus it perceives that national security is something that cannot and will not be compromised to the point in which no relation is established between defense and economy. Accordingly, Taiwan's defense demand is very inelastic to the change in the resource availability. Singapore is at the opposite of Taiwan. Despite its scant concerns about the external threat, Singapore spends a high level of military expenditure. However, since its primary motive lies in the economic consideration, Singapore is actively involved in regional affairs and thus regards the military expenditure just like any other expenditure. In other words, if you can afford it, you enjoy it; if you find yourself short of money, you give it up. South Korea stands in the middle between Taiwan and Singapore. Faced with the unpredictable North Korea, South Korea persistently places a high priority on the needs of national security. Yet limited in its natural resource endowment, South Korea is comparatively sensitive about balancing its military needs with other economic demands. Despite its relatively heavy defense burden, South Korea shows more flexibility in compromising its defense demands with its impending demands from private economic sectors, partly because it benefits from a formal military alliance with the United States, and partly because its perception of defense needs is subjected to political demands.

60) Chan 1991, 1992. Ones commitment to spend, after all, does not always lead to the actual disbursement of expenditure. 
Although South Korea, Singapore, and Taiwan are similar in many respects, their way of balancing goals in defense and growth vary rather distinctively. By interpreting the behavior of a country according to the degree of 'security-prosperity dilemma' perception, the elasticity model explains the interstate difference in a systematic manner. This paper starts with a caution that the data need to be handled carefully because of its shortcomings in accuracy and completeness. My concern remains unchanged that the limitation imposed by the data availability impedes a thorough analysis of the interconnection in the military expenditure and the economic performance. Nevertheless, I believe that this paper makes a contribution to the study of economics of defense for a couple of reasons.

First, while most explanatory models of such interconnection target the developed countries in which deviation from the expectation is rarely found or a scholarly focus is largely limited to cross-sectional analysis on the basis of resource constraint, thus the complication arises when trying to apply the identical model to LDCs, I purposefully choose NICs considered between the less developed and developed countries in terms of the level of economic development. In so doing, this paper shows that the anticipated complexity is accountable in a systematic rather than ad hoc way. Second, I confine the analysis to three Asian NICs that share the similar political culture and other aspects, thus extricating other complications in the explanatory model. On the basis of such a restriction, this paper integrates the causality and elasticity models into an explanatory framework to account for the observed difference among the three Tigers in their perception of defense needs. 


\section{References}

Adams, F. Gerard, et al. "Government expenditure, defense and economic growth in the LDCs: A revised perspective." Conflict Management and Peace Science 11 (1991).

Ball, Desmond. "Arms and affluence: Military acquisitions in the Asia-Pacific region." International Security 18-3 (1993/1994).

Ball, Nicole. "Defense and development: Critique of the Benoit study." Economic Development and Cultural Change 31 (1983).

Benoit, Emile. Defense and Economic Growth in Developing Countries.(Boston: Lexington Books) 1973.

"Growth and defense in developing countries." Economic Development and Cultural Change 26 (1978).

Berthelemy, J. C. "Military expenditure and economic development: An endogenous growth perspective." Economics of Planning 28-2 (1995).

Betts, Richard. Military Readiness: Concept, Choices, Consequences. (Washington, D.C.: The Brookings Institute) 1995.

Biswas, Basudeb and Rati Ram. "Military expenditures and economic growth in less developed countries: An augmented model and further evidence." Economic Development and Cultural Change 34 (1986).

Biswas, Basudeb. "Defense spending and economic growth in developing countries," in Defense Spending and Economic Growth, James Payne and Anandi Sahu eds. (Bounder: Westview Press) 1993.

Chan, Steve. "The impact of defense spending on economic performance: A survey of evidence and problems." Orbis Summer (1985).

. "Military expenditures and economic performance." ACDA: World Military Expenditure and Arms Transfers (1987).

"The political economy of military spending and economic performance: Directions for future research," in The Political Economy of Defense: Issues and Perspectives. Andrew Ross ed. (New York: Greenwood Press) 1991.

"Military burden, economic growth, and income inequality: The Taiwan exception," in Defense, Welfare, and Growth. Steve Chan and Alex Mintz eds. (London: Routledge) 1992.

Chan, Steve, and David Davis. "Granger Causality in Taiwan's Defense Economics," in The Political Economy of Defense: Issues and Perspectives. Andrew Ross ed. (New York: Greenwood Press) 1991.

Chowdhury, Abdr. "A causal analysis of defense spending and economic growth." Journal of Conflict Resolution 35-1 (1991).

Davis, David, and Steve Chan. "The security-welfare relationship: Longitudinal evidence from Taiwan," in Defense, Welfare, and Growth. Steve Chan and Alex Mintz eds. (London: Routledge) 1992. 
Deger, Saadet. Military expenditures in Third World countries: The economic effects. (London: Routledge \& Kegan Paul) 1986.

Deger, Saadet and Somnath Sen. "Military expenditure, spin-off and economic development." Journal of Development Economics 13 (1983). . Military Expenditure: The Political Economy of International Security. (Oxford: Oxford Univ. Press) 1990.

Deger, Saadet and R. P. Smith. Military expenditure and growth in less developed countries. Journal of Conflict Resolution 27 (1983).

Directorate General of Budget, Accounting and Statistics. Statistical Yearbook of the Republic of China. (Executive Yuan: The Republic of China) various years.

Dunne, J. P. "Economic effects of military expenditure in developing countries: A survey." Contributions to economic analysis 235 (1996).

Feder, Gershon. "On exports and economic growth." Journal of Development Economics 12 (pp. 59-73, 1982).

Frederiksen, P. C. and C. J. LaCivita. "Defense spending and economic growth: Time series evidence on causality for the Philippines." Journal of Philippine Development 25 (1987).

Frederiksen, P. C. and Robert Looney. "Defense expenditures and economic growth in developing countries." Armed Forces and Society 9 (1982).

"Defense expenditures and economic growth in developing countries: Some further empirical evidence." Journal of Economic Development 7 (1983).

Granger, C. W. J. "Investigating causal relations by econometric models and cross-spectral methods." Econometrica 37 (1969).

Harris, Geoffrey. "The determinants of defense expenditure in the ASEAN region." Journal of Peace Research 23 (1986).

. "Economic aspects of military expenditure in developing countries: A survey article." Contemporary Southeast Asia 10 (1988).

Heo, Uk. "The political economy of defense spending in South Korea." Journal of Peace Research 34-1 (1990).

. "Modeling the defense-growth relationship around the globe." The Journal of Conflict Resolution 42-5 (1998).

Heo, Uk, and Karl DeRouen, Jr. "Military expenditure, technological change, and economic growth in the East Asian NICs." Journal of Politics 60-3 (1998).

Heo, Uk, and Kwang-Hae Ro. "Review essay: The economic effects of military spending on growth in developing countries." The Journal of East Asian Affairs 12-1 (1998).

Hong, Okyeon. Three Tigers and Defense. Masters thesis. State University of New York, Binghamton (1992).

Hsiao, Cheng. "Causality tests in econometrics." Journal of Economic Dynamics and Control 1 (1979).

. "Autoregressive modeling and money-income causality detection." Journal of Monetary Economics 7 (1981). 
Huang, Chi, and Alex Mintz. "'Guns' vs. 'butter': Conceptual and methodological issues." Policy Studies Review 11-3/4 (1992).

International Monetary Fund. International Financial Statistics Yearbook (various years). Joerding, Wayne. "Economic growth and defense spending: Granger causality," Journal of Development Economics 21 (1986).

Kusi, Newman. "Economic growth and defense spending in developing countries." Journal of Conflict Resolution 38-1 (1994).

LaCivita, Charles, and Peter Frederiksen. "Defense spending and economic growth: An alternative approach to the causality issue." Journal of Development Economics 35 (1991).

Li, C. P. "Fear, greed, or garage sale?: The analysis of military expenditure in East Asia." Pacific Review 10-2 (1997).

Lim, David. "Another look at growth and defense in less developed countries." Economic Development and Cultural Change 31 (1983).

Looney, Robert. "Defense expenditures and economic performance in South Asia: Tests of causality and interdependence." Conflict Management and Peace Science 11-2 (1991).

Looney, Robert and P. C. Frederiksen. "Defense expenditures, external public debt and growth in developing countries." Journal of Peace Research 23 (1986).

Maizels, Alfred and Machiko Nissanke. "The determinants of military expenditure in developing countries." World Development 14 (1986).

Mintz, Alex, and Randolph Stevenson. "Defense expenditures, economic growth, and the peace dividend." Journal of Conflict Resolution 39-2 (1995).

Mintz, Alex, and Chi Huang. "Guns versus butter: The indirect link." American Journal of Political Science 84-4 (1991).

Mintz, Alex, Chi Huang, and Uk Heo. "Defense spending and economic performance: A disaggregated analysis," in Defense, Welfare, and Growth: Perspectives and Evidence. Steve Chan and Alex Mintz eds. (London: Routledge) 1992.

Moon, Chung-in and In-Taek Hyun. "Muddling through security, growth, and welfare: The political economy of defense spending in South Korea," in Defense, Welfare, and Growth: Perspectives and Evidence. Steve Chan and Alex Mintz eds. (London: Routledge) 1992.

Palmer, Glenn. "Deterrence, defense spending, and elasticity: Alliance contributions to the public good." International Interactions 17 (1991).

Park, Kun Y. "'Pouring new wine into fresh wineskins': Defense spending and economic growth in LDCs with application to South Korea." Journal of Peace Research 30-1 (1993).

Ram, Rati. "Conceptual linkages between defense spending and economic growth and development: A selective view." In Defense Spending and Economic Growth. James Payne and Anandi Sahu eds. (Boulder: Westview Press) 1993.

Rothchild, Kurt. "Military expenditure, exports and growth." Kyklos 26 (1977). 
Sandler, Todd, and Keith Hartley. The Economics of Defense. (Cambridge: Cambridge Univ. Press) 1995.

Shambaugh, David. "Exploring the complexities of contemporary Taiwan." The China Quarterly (1996).

Smith, Ron. "Measuring the effects of military spending: Cross-sections or time-series?" in The Economics of International Security, Manas Chatterji and Henk Jager eds. (New York: St. Martins Press) 1994.

Stockholm International Peace Research Institute. SIPRI Yearbook: Armaments, Disarmaments and International Security. (Oxford: Oxford Univ. Press) various years.

Ward, Michael, David Davis, and Steve Chan. "Military spending and economic growth in Taiwan." Armed Forces \& Society 19-4 (1993).

Willett, Susan. "East Asias changing defense industry." Survival 39-3 (1997).

Yi Hong, Okyeon. "Theorizing about defense and performance: A selective research assessment," Journal of National Security 8, (2003). 